\title{
Penyuluhan dan Tatalaksana Etika Batuk Dan Bersin Sebagai Pencegahan Penyakit ISPA di Kabupaten Gowa
}

\author{
Zulfitriani Murfat ${ }^{1}$, Rachmat Faisal Syamsu ${ }^{2}$, Wawan Susilo ${ }^{3}$ \\ ${ }^{1}$ Departemen Biokimia, Fakultas Kedokteran, Universitas Muslim Indonesia, Makassar, Indonesia \\ ${ }^{2}$ Depertemen Ilmu Kesehatan Masyarakat, Fakultas Kedokteran, Universitas Muslim Indonesia, Kota \\ Makassar, Indonesia \\ ${ }^{3}$ Depertemen Anatomi, Fakultas Kedokteran, Universitas Muslim Indonesia, Kota Makassar, Indonesia \\ *Email Korespondensi: pithoweety86@gmail.com \\ Telp: +62-1343862003
}

\begin{abstract}
ABSTRAK
Infeksi Saluran Pernapasan Akut (ISPA) merupakan penyakit yang ditularkan melalui droplet yang diketahui atau tidak diketahui penyebabnya. Penularan dapat terjadi melalui kontak (termasuk kontaminasi tangan oleh sekret saluran pernapasan, mulut dan hidung) dan melalui udara dengan jarak dekat saat dilakukan tindakan yang berhubungan dengan saluran napas. Untuk mencegah penularannya maka penting untuk tidak mengabaikan pencegahan dan pengendalian infeksi untuk mencegah kejadian luar biasa. Metode yang digunakan dengan memberikan penyuluhan dan tatalaksana etika batuk dan bersin yang benar sebagai upaya pencegahan penyakit infeksi saluran napas atas (ISPA) di Kabupaten Gowa.
\end{abstract}

Kata kunci: Etika batuk; batuk; bersin; ISPA; Gowa

\begin{abstract}
Acute Respiratory Infection (ISPA) is a disease transmitted through droplets that are known or unknown causes. Transmission can occur through contact (including contamination of the hands by the secretions of the respiratory tract, mouth and nose) and through the air at close range when airwayrelated actions are performed. To prevent its transmission it is important not to neglect the prevention and control of infections to prevent extraordinary events. The method used by providing counseling and ethical procedures of coughing and sneezing is correct as an effort to prevent upper respiratory tract infection disease (ISPA) in Gowa Regency.
\end{abstract}

Keywords: Cough etiquette; Cough; Sneezing; Acute respiratory tract infection; Gowa 


\section{PENDAHULUAN}

Angka morbiditas dalam menggambarkan kejadian penyakit sangat berperan dalam penilaian terhadap derajat kesehatan. Berdasarkan Profil Kesehatan Indonesia tahun 2010 menunjukkan bahwa 10 penyakit terbanyak salah satunya adalah ISPA dengan persentase CFR $3,29 \%$ (1). Pengendalian infeksi saluran pernapasan akut pada pasien, khususnya jenis ISPA yang diderita sangat penting untuk mengurangi resiko penyebaran infeksi. Sebagian dari penyakit ini berpotensi menyebar dengan cepat dan bias menimbulkan dampak serius terhadap kesehatan publik (2). Pada era timbulnya ancaman berbagai penyakit menular, hendaknya jangan mengabaikan pentingnya pencegahan dan pengendalian infeksi di fasilitas pelayanan kesehatan untuk mencegah kejadian luar biasa. Pola penyebaran ISPA yang utama adalah melalui droplet yang keluar dari hidung/mulut penderita saat batuk atau bersin. penularan juga dapat terjadi melalui kontak (termasuk kontaminasi tangan oleh sekret saluran pernapasan, hidung, dan mulut) dan melalui udara dengan jarak dekat saat dilakukan tindakan yang berhubungan dengan saluran napas. Salah satu faktor risiko terjadinya ISPA adalah perilaku merokok (3). Karena banyak gejala ISPA yang tidak spesifik dan tes diagnosis cepat selalu tersedia, maka etiologi kadang sering tidak diketahui dengan segera. Dengan demikian hal ini menjadi tantangan bagi fasilitas pelayanan kesehatan untuk memberikan pelayanan kepada pasien ISPA dengan etiologi dan pola penularan yang diketahui ataupun yang tidak diketahui (4).

Etika batuk merupakan salah satu komponen perilaku pencegahan penularan dengan tindakan memalingkan kepala dan menutup mulut atau hidung dengan tisu apabila tidak terdapat tisu maka mulut dan hidung bisa ditutup oleh tangan atau pangkal (5). Penelitian yang dilakukan oleh Barry et al mengenai respiratory hygiene pada masyarakat yang diobservasi mengenai etika batuk, menunjukkan hanya $4,7 \%$ yang menerapkan etika batuk yang benar, sebanyak 64,4\% menutup hidung dan mulut tidak memakai tangan dan 27,3\% mulut dan hidung tidak ditutup saat batuk dan bersin (6). Pendidikan kesehatan dalam waktu pendek menghasilkan perubahan atau peningkatan pengetahuan, dan dalam jangka menengah dapat berpengaruh pada perilaku seseorang. Pendidikan kesehatan pada hakikatnya adalah suatu kegiatan atau usaha untuk menyampaikan pesan kesehatan kepada masyarakat, kelompok dan individu. Dengan harapan bahwa dengan adanya pesan tersebut masyarakat kelompok atau individu dapat memperoleh pengetahuan tentang kesehatan yang lebih baik. Akhirnya pengetahuan tersebut diharapkan dapat berpengaruh terhadap perilakunya. Pengetahuan individu sangat penting karena merupakan dominan dalam membentuk tindakan seseorang. 
Perilaku yang didasari oleh pengetahuan akan lebih langgeng daripada perilaku yang tidak didasari pengetahuan. Pendidikan kesehatan tentang ISPA merupakan usaha atau kegiatan untuk membantu individu, kelompok atau masyarakat terutama orang tua dalam meningkatkan pengetahuan dan kemampuan mereka dalam perawatan balita ISPA sehingga kualitas kesehatan tercapai secara optimal. ISPA merupakan salah satu penyakit infeksi menular yang menjadi prioritas nasional. Hasil penelitian yang dilakukan oleh Tria et al menunjukkan informan memiliki kriteria usia 36-45 tahun, sebagian besar informan laki-laki, dengan tingkat pendidikan SMP dan SMA, dan sebagian besar informan memiliki pengetahuan tentang penyakit ISPA yang cukup baik (7). Penelitian yang dilakukan oleh Brown et al pada studi kualitatif yang dilakukan di Inggris secara konseptual memfokuskan fokus mengenai etika batuk dan cara batuk yang benar. Pertama bagaimana batuk dengan etik yang baik dapat mengurangi kecemasan polusi lingkungan. Kedua batuk melalui media pelatihan professional dan intervensi. Etika batuk yang benar dianggap dapat memiliki "waktu dan tempat" dalam membatasi hal yang berisiko di ruang publik (8). Patmawati et al juga menyebutkan bahwa ada hubungan antara kepadatan hunian dengan kejadian ISPA (9). Hal ini tidak seperti yang dikemukakan pada penelitian yang dilakukan oleh Prateek et al bahwa pengetahuan dan praktik etika batuk ditemukan tidak memuaskan dalam penelitian ini. Dengan demikian, sudah saatnya untuk mengatasi masalah ini dan menjembatani kesenjangan pengetahuan serta praktik etika batuk di kalangan masyarakat umum untuk mengurangi penularan dari orang ke orang dan dengan demikian mengurangi beban infeksi saluran pernapasan (10).

\section{METODE PELAKSANAAN}

\subsection{Solusi dan Target Luaran (contoh)}

Kegiatan penyuluhan dan tata cara etika batuk dan bersin yang baik dan benar ini memberikan pemahaman pengetahuan tentang pentingnya pengendalian dan pencegahan penyakit ISPA serta perubahan perilaku berdasarkan etika batuk dan bersin yang benar. Dengan target luaran peserta dapat memahami tata cara etika batuk dan bersin yang benar melalui pengisian kuesioner sebelum dan setelah kegiatan penyuluhan. Pengisian kuesioner pretest dengan nilai rata-rata 66\% dan kuesioner posttest dengan nilai rerata $87 \%$.

\subsection{Lokasi Kegiatan Pelaksanaan (contoh)}

Kegiatan ini dilaksanakan pada tanggal 24 Oktober 2019 di Pesantren Hasanuddin, Gowa. Kegiatan ini dihadiri 46 peserta yang terdiri atas siswa siswi Madrasah Aliyah 
kelas XII Pesantren Hasanuddin, Kabupaten Gowa.

\subsection{Metode Kegiatan}

Kegiatan ini dilakukan dengan metode memberikan penyuluhan tentang pentingnya etika batuk dan bersin yang benar setelah pengisian kuesioner pretest untuk menilai tingkat pemahaman peserta. Simulasi tata cara batuk dan bersin yang benar dilakukan setelah penyuluhan dan dilakukan feed back dengan membagikan kuesioner posttest.

\section{HASIL DAN PEMBAHASAN}

Pengabdian kepada masyarakat yang dilakukan di Pesantren Hasanuddin, Gowa dihadiri oleh siswa dan siswi sebanyak 46 orang yang terdiri atas 33 perempuan dan 13 laki-laki. Berdasarkan jumlah peserta berdasarkan jenis kelamin yakni 15 orang laki-laki (31\%) dan perempuan berjumlah 33 orang (69\%). Hasil kuesioner sebelum penyuluhan tentang etika batuk dan bersin yang benar sebanyak 44 orang yang menjawab "Ya" dengan persentase 66\% sedangkan sebanyak 23 orang yang menjawab "Tidak" dengan persentase $34 \%$. Hasil kuesioner setelah penyuluhan tentang etika batuk dan bersin yang benar sebanyak 36 orang dengan jawaban "Ya" dengan persentase $87 \%$ dan yang menjawab "Tidak" sebanyak 10 orang dengan persentase $13 \%$. Hal ini juga diperlihatkan dengan persentase hasil simulasi etika batuk dan bersin yang benar sebanyak 54 orang $(74 \%)$ dan 19 orang (26\%) yang belum tepat melakukannya. Hal ini menjadi salah satu bentuk aspek perilaku dan kebiasaan yang dapat diterapkan di lingkungan masyarakat guna mencegah pengendalian penyakit infeksi khususnya ISPA.

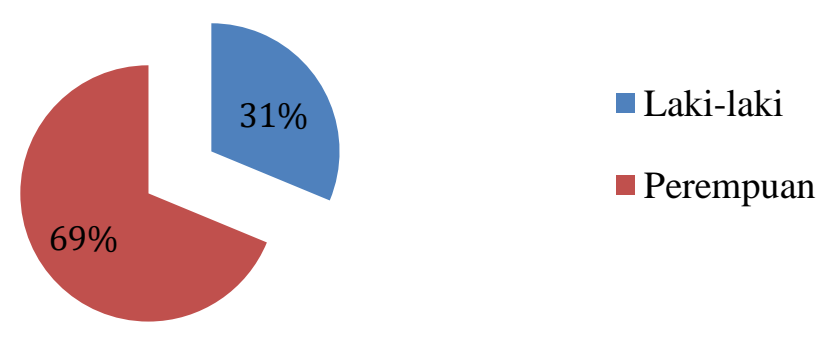

Gambar 3.1. Distribusi Jumlah Peserta Yang Hadir di Pesantren Hasanuddin, Gowa 


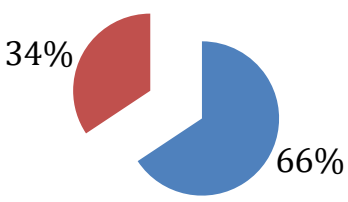

Ya $\quad$ Tidak

Gambar 3.2. Persentase Jumlah Peserta Yang Paham Tentang Etika Batuk dan Bersin Yang Benar Sebelum Penyuluhan

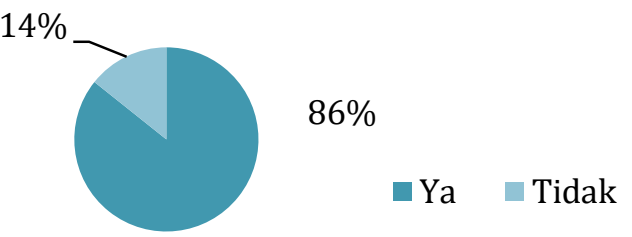

Gambar 3.3. Persentase Jumlah Peserta Yang Paham Tentang Etika Batuk dan Bersin Yang Benar Setelah Penyuluhan
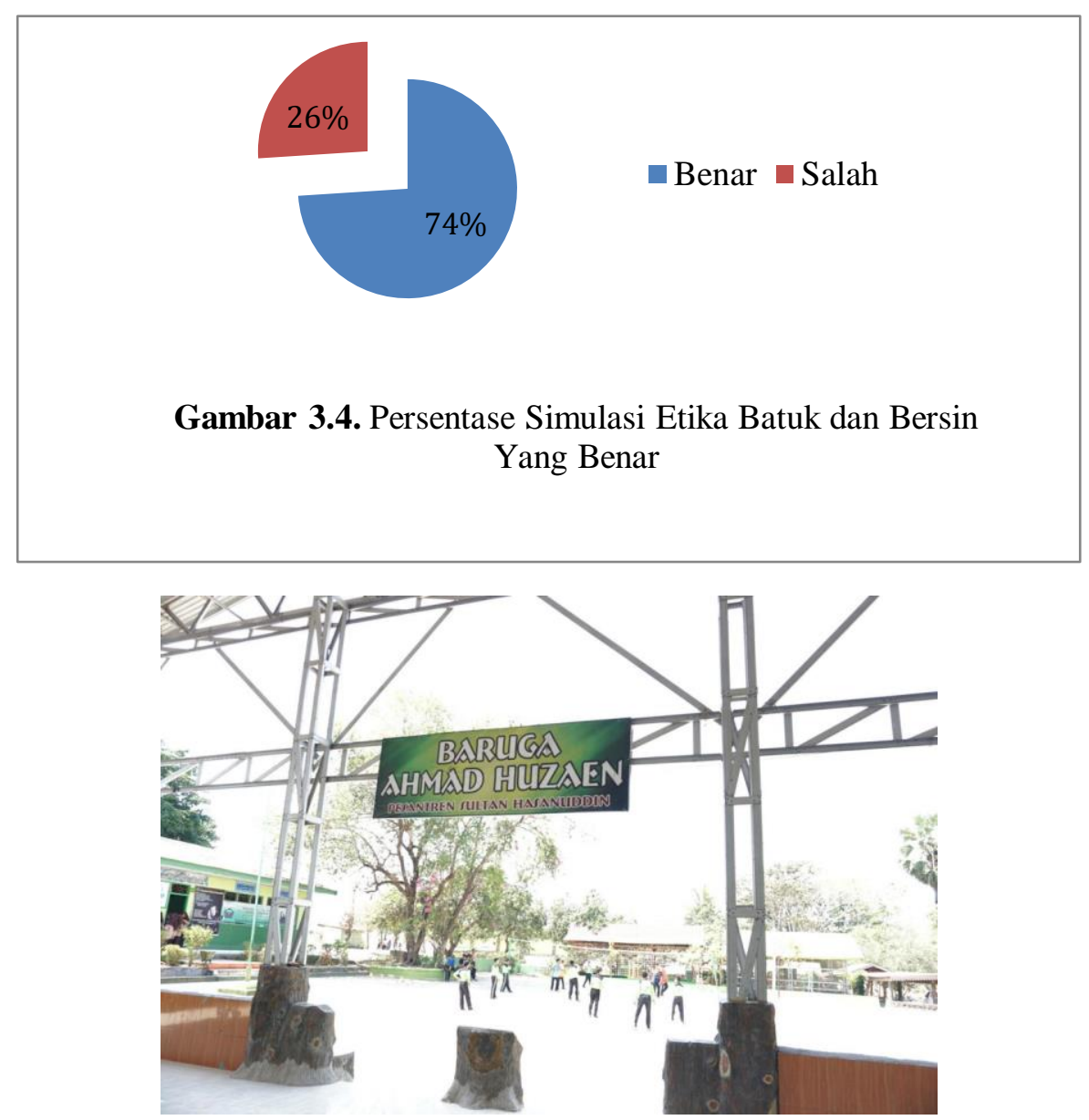

Gambar 3.5. Baruga Tempat Kegiatan Penyuluhan Pesantren Hasanuddin, Kabupaten Gowa 


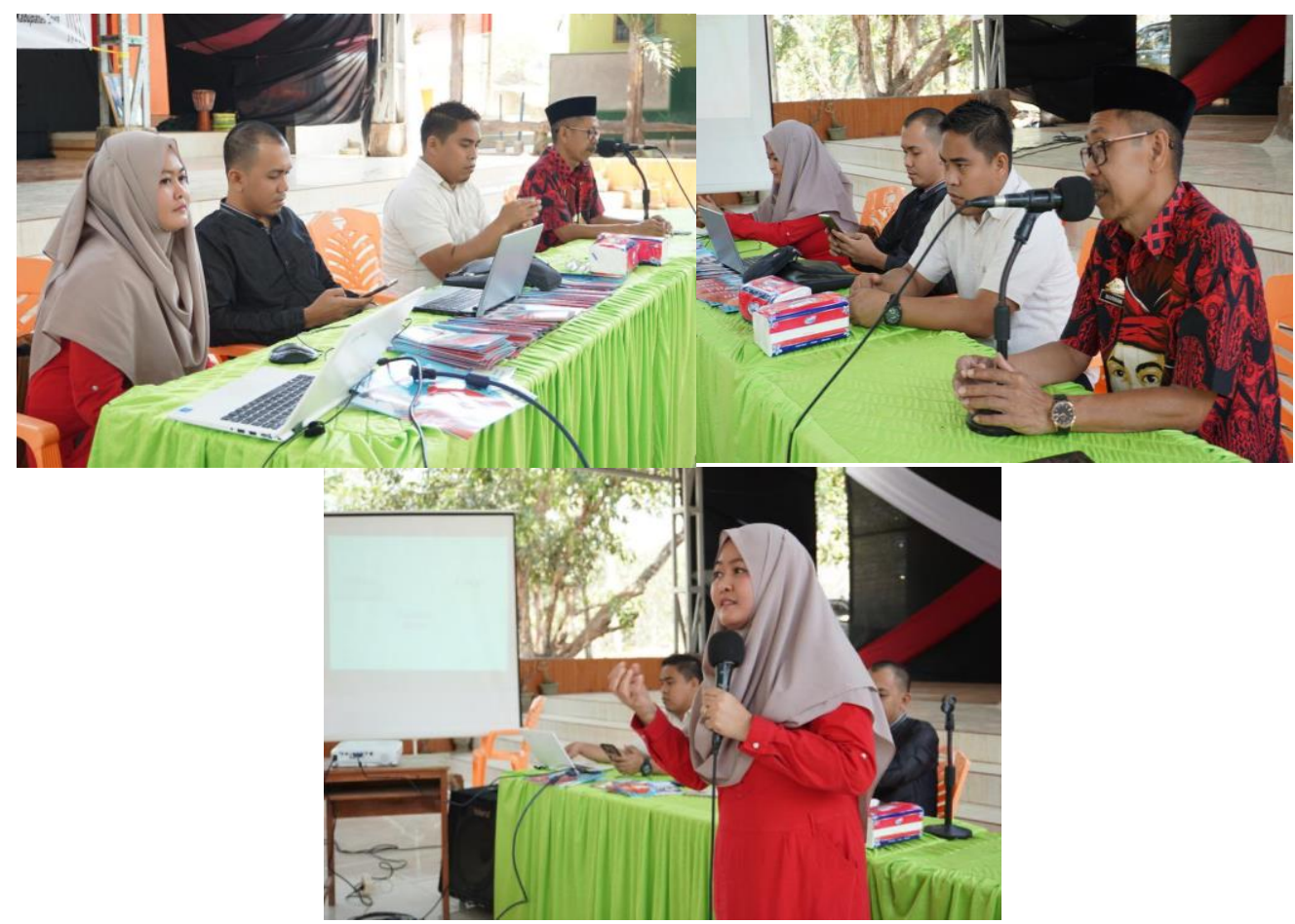

Gambar 3.6. Pembukaan Kegiatan Penyuluhan
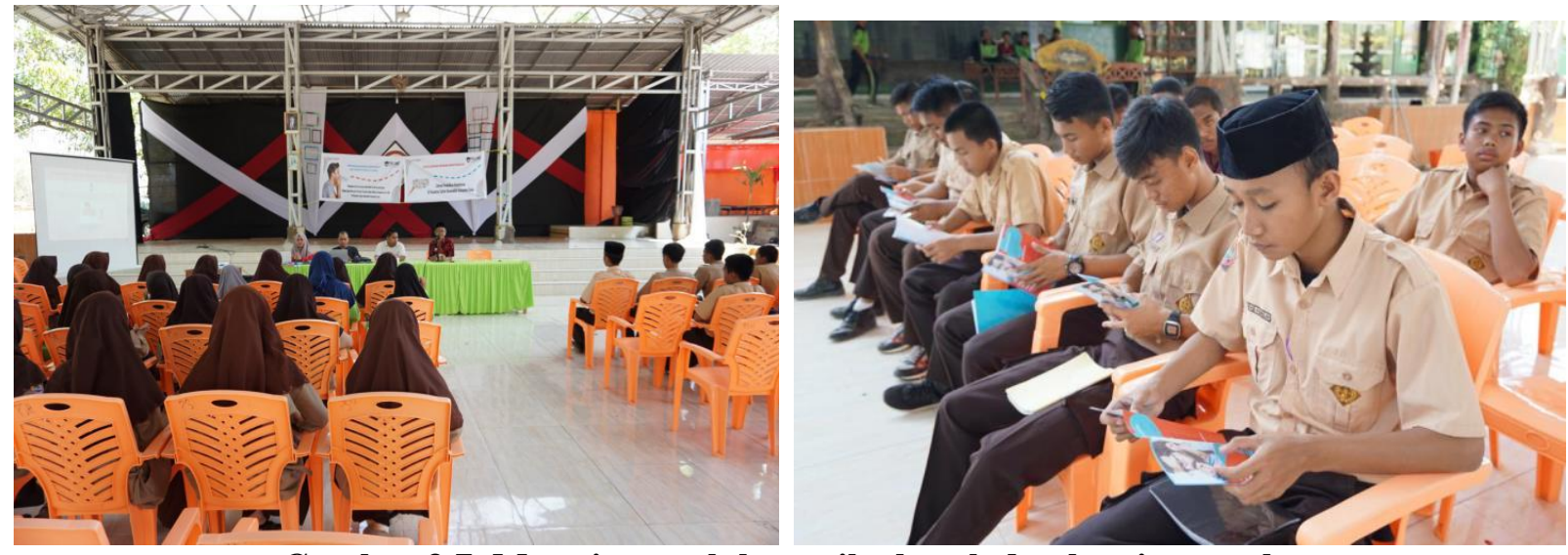

Gambar 3.7 Materi penyuluhan etika batuk dan bersin yang benar

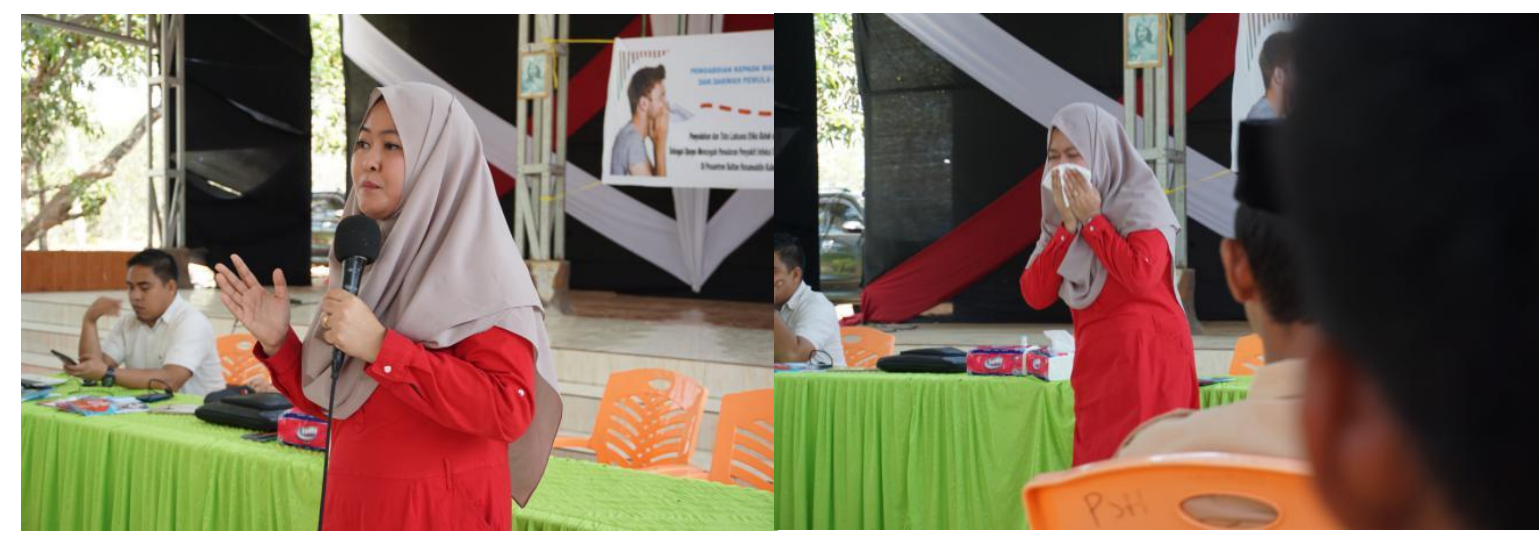

Gambar 3.8 Simulasi Tata Laksana Etika Batuk dan Bersin Yang Benar 


\section{KESIMPULAN DAN SARAN}

Simpulan dari kegiatan pengabdian kepada masyarakat ini dengan mengetahui dan memahami pentingnya pencegahan dini penyakit infeksi membantu masyarakat dan pelayanan kesehatan dalam mengendalikan penyakit infeksi dan juga menanamkan bentuk kebiasaan dan perilaku yang baik dan benar dengan menerapkan etika batuk yang benar.

\section{Ucapan Terima Kasih}

Terselenggaranya kegiatan ini tidak lepas dari peran dukungan dan kerjasama kepada pihak yang telah membantu kelancaran kegiatan ini, (1) kepada institusi kami yang telah memberikan dukungan moril dan fasilitas untuk membantu kegiatan tri dharma perguruan tinggi bagi dosen

(2) pihak mitra yang telah mempercayakan kepada kami untuk menyelenggarakan kegiatan ini (3) serta pihak lain yang terkait mulai dari proses perencanaan hingga hasil ini terselenggarakan dengan baik.

\section{DAFTAR PUSTAKA}

1. Kesehatan K. Pusat Data dan Informasi Profil Kesehatan Indonesia 2010 [Internet]. Direktorat Jendral Kesehatan Ibu dan Anak. 2011. Jakarta. Available from: http://www.depkes.go.id

2. WHO. Infeksi Saluran Pernapasan Akut (ISPA). Who Indones Partn Dev. 2008;53(2):825 .

3. Aprilla N, Yahya E, Ririn. Hubungan Perilaku Merokok pada Orang tua dengan Kejadian ISPA pada Balita di Desa Pulau Jambu Wilayah Kerja Puskesmas Kuok Tahun 2019. J Ners. 2019;3(1):112-8.

4. Dan W, Epidemi T, Pandemi DAN. Infeksi saluran pernapasan akut ( ISPA ) yang cenderung epidemi dan Pandemi Pencegahan dan Pengendalian ISPA di Fasilitas Pelayanan Kesehatan Strategi Kunci. 2008;5-6.

5. Ramdan M, Lukman M, Platini H. Pengetahuan, sikap dan etika batuk pada penderita tuberkulosis paru. Holistik J Kesehat. 2020;14(2):232-9.

6. Barry T, Manning S, Lee MS, Eggleton R, Hampton S, Kaur J, et al. Respiratory hygiene practices by the public during the 2009 influenza pandemic: An observational study. Influenza Other Respi Viruses. 2011;5(5):317-20.

7. Karanganyar BK. Gambaran Karakteristik Dan Pengetahuan Penderita Ispa Pada Pekerja Pabrik Di Pt Perkebunan Nusantara Ix (Persero) Kebun Batujamus/ Kerjoarum Karanganyar. J Heal Educ. 2018;3(1):58-64. 
8. Brown N, Nettleton S, Buse C, Lewis A, Martin D. The coughing body: etiquettes, techniques, sonographies and spaces. Biosocieties [Internet]. 2020;(0123456789). Available from: https://doi.org/10.1057/s41292-020-00196-3

9. Dongky P, Kadrianti K. Faktor Risiko Lingkungan Fisik Rumah Dengan Kejadian Ispa Balita Di Kelurahan Takatidung Polewali Mandar. Unnes J Public Heal. 2016;5(4):324.

10. Shrivastava PS, RamBihariLal Shrivastava S. A cross sectional study to assess the awareness and practice about cough etiquettes among respiratory symptomatic patients in Tamil Nadu. Int J Community Med Public Heal. 2019;6(10):4248. 